\title{
SYNE1 Gene
}

National Cancer Institute

\section{Source}

National Cancer Institute. SYNE1 Gene. NCI Thesaurus. Code C150327.

This gene plays a role in subcellular spatial organization. 